\title{
Uterotonic effect of rectal misoprostol as preoperative medication for assessment of intraoperative and postoperative blood loss in cesarean delivery
}

\author{
Urmila Karya, Shweta Maheshwari*, Anupam Rani
}

Department of Obstetrics and Gynaecology, LLRM Medical College, Meerut, Uttar Pradesh, India

Received: 14 November 2019

Revised: 18 February 2021

Accepted: 26 December 2021

\section{*Correspondence:}

Dr. Shweta Maheshwari,

E-mail: Shweta_sims@yahoo.co.in

Copyright: (C) the author(s), publisher and licensee Medip Academy. This is an open-access article distributed under the terms of the Creative Commons Attribution Non-Commercial License, which permits unrestricted non-commercial use, distribution, and reproduction in any medium, provided the original work is properly cited.

\begin{abstract}
Background: Postpartum hemorrhage is the leading cause of maternal mortality and it's prevention has been identified as key component of safe motherhood. Misoprostol is an effective uterotonic for prophylaxis and control of PPH. Aim of our study was to evaluate the effect of preoperative rectal misoprostol $(400 \mu \mathrm{g})$ on blood loss during and after cesarean delivery.

Methods: It was a randomised controlled trial done on 200 women scheduled for elective cesarean delivery. Eligible participants were randomized into two groups. In the study group 100 women received a preoperative $400 \mu \mathrm{g}$ per rectal misoprostol tablet just after spinal anaesthesia while 100 women assigned to the control group did not receive misoprostol tablet.

Results: The mean intra operative and postoperative blood loss was lower in study group than the control group $345.98 \pm 79.57 \mathrm{ml}$ and $114 \pm 19.97 \mathrm{ml}$ versus $408.6 \pm 63.68 \mathrm{ml}$ and $136.38 \pm 24.81 \mathrm{ml}$, respectively. The difference between the preoperative and postoperative hematocrit values was also significantly lower in the study group than the control group (33.43 \pm 1.93 and 33.64 \pm 1.82 )

Conclusions: In our study it was concluded that preoperative $400 \mu \mathrm{g}$ rectal misoprostol is effective in reducing intraoperative and postoperative blood loss, thus preventing postpartum hemorrhage and reducing incidence of overall maternal morbidity and mortality.
\end{abstract}

Keywords: Misoprostol, Preoperative medication, Caesarean delivery, Postpartum hemorrhage

\section{INTRODUCTION}

Postpartum hemorrhage is a major contributor to maternal mortality and morbidity during vaginal or cesarean delivery mainly in developing countries and its prevention is assume to be important and rational strategy for preventing maternal mortility and morbidity. The maternal mortality ratio in developing countries in 2015 is 239 per 100,000 live births versus 12 per 100,000 live births in developed countries. ${ }^{1}$ Every year about 14 million women around the world suffer from postpartum hemorrhage
(PPH) and the risk of maternal mortality from hemorrhage is 1 in 1000 deliveries in developing countries (100 per 100000 live births). ${ }^{2}$

Misoprostol has proven to be an effective uterotonic. ${ }^{3}$ It is widely used for management of the third stage of labor. ${ }^{4}$ It is also used for intractable postpartum hemorrhage when other medical interventions failed. ${ }^{5}$ It is easily available, cheap, stable at room temperature and easily administered. ${ }^{6}$ Misoprostol has a shelf life of several years and hence does not require specific condition for storage. 
Also it is a water-soluble drug and is quickly absorbed after sublingual, oral, vaginal, and rectal use. Side effects of misoprostol are mild such as shivering, pyrexia, nausea, vomiting, diarrhoea and usually occur at high doses. ${ }^{7}$ Rectal misoprostol is the best route for patient undergoing cesarean delivery due to slower absorption, lower peak levels, sustained effect, fewer side effects compared with oral and sublingual route. ${ }^{8}$ The mean Tmax after rectal administration is $40-65$ minutes. This delayed timing of absorption is thought to be beneficial when misoprostol is given prior to cesarean delivery as by the end of cesarean section, the maximum effect is obtained. ${ }^{9}$

Many research studies have been conducted to evaluate the role of rectal misoprostol in prevention and treatment of postpartum hemorrhage. However, its use in conjunction with cesarean delivery as a preoperative medication for prevention of PPH has not been investigated as much and there are very few studies regarding usage of preoperative rectal administration in cesarean cases. Hence in this study an attempt has been made to assess the role of preoperative per rectal misoprostol in preventing or reducing PPH in cesarean delivery.

\section{METHODS}

This study was a randomised controlled trial conducted in the department of Obstetrics and Gynaecology, L.L.R.M. Medical College Meerut during one year period from May 2017 to June 2018. A total of 200 women scheduled for elective cesarean delivery, who met inclusion criteria, were enrolled in this study with informed consent. Ethical clearance was taken from the institutional ethics committee.

Eligible participants were randomized into two groups using computer generated random table. In the study group 100 women received a preoperative $400 \mu \mathrm{g}$ (microgram) per rectal misoprostol tablet just after spinal anaesthesia while 100 women assigned to the control group did not receive misoprostol tablet.

\section{Inclusion criteria}

Uncomplicated singleton term pregnancies (37-40 weeks), up to 4th parity, scheduled for elective cesarean delivery.

\section{Exclusion criteria}

Antepartum hemorrhage, traumatic postpartum hemorrhage during cesarean, history of previous 2 or more cesarean section, multiple pregnancy, fetal distress, fetal macrosomia, polyhydramnios, previous history of uterine rupture repair, history of previous uterine surgery (metroplasty, myomectomy), patient in active labour, congenital uterine anomaly, history of hypersensitivity or contraindication to prostaglandins, medical disorder (heart disease diabetes mellitus, severe anaemia, severe PIH and eclampsia) and coagulation disorders.
In subjects the complete history with details of gravida, parity, gestational age was noted down. Indication for present cesarean section and associated comorbid factors were noted. Complete clinical evaluation was done. Routine laboratory investigations with particular emphasis on blood indices (hemoglobin and hematocrit) were done. Subjects with abnormal test results were excluded from study. Detailed sonographic examination, was performed. Eligible candidates were randomised in two groups. Women in study group received a preoperative 400 microgram misoprostol tablet, rectally after spinal anaesthesia and urinary bladder catheterisation while, women in control group did not receive misoprostol tablet. Cesarean delivery was performed under spinal anaesthesia by senior obstetricians who were blind to allocation. All participant received 20 IU of oxytocin in $500 \mathrm{ml}$ lactated ringer solution after cord clamping. The placenta was delivered by controlled cord traction. The uterus was closed in situ in continuous suture in double layer. The parietal peritoneum was closed by vicryl 0 . Rectus sheath was closed by vicryl 1 and skin was closed by nonabsorbable suture material.

Estimation of blood loss was started after uterine incision. During the operation an isolated suction was used for evacuation of amniotic fluid through a small incision over the uterus, and another one used for collection of blood. A dedicated nurse was responsible for collection of blood and amniotic fluid in 2 separate suction sets, and for weighing surgical towels before and after operation. Amount of blood collected in suction jar was noted. Fixed size mops $(20 \times 20 \mathrm{~cm})$ were used in present study. One gram of weight difference was equal to $1 \mathrm{ml}$ of blood. One fist full of clot was taken equivalent of 500 millilitre of blood. A highly accurate digital balance was used for weighing swabs. The surgeon requested additional uterotonic agents on the basis of clinical findings during surgery. Postpartum blood loss during the first twenty-four hour after the operation was assessed by weighing soaked napkins and clots if any. Hemoglobin was measured before surgery and 24 hours after the operation to document change in hemoglobin and hematocrit level.

\section{RESULTS}

In present clinical study most of the women were in the age group $21-25$ years (62\% and $52 \%$ respectively) followed by age group 26-29 years (25\% and 33\% respectively).

A total $65 \%$ women in study group and $67 \%$ women in control group were of rural background.

Most of the women who underwent caesarean both groups were either gravida $2(66 \%$ and $60 \%$ respectively) or primigravida (29\% and $33 \%$ respectively) with mean gestational age of $37.803 \pm 0.51$ and $37.768 \pm 0.47$ respectively. In study group 55\% women and $48 \%$ women in control group had undergone repeat caesarean. (Table1) 
Table 1: Distribution of socio-demographic factors.

\begin{tabular}{|c|c|c|c|c|}
\hline $\begin{array}{l}\text { Socio-demographic } \\
\text { factors }\end{array}$ & Variables & Group A (study group) & Group B (control group) & p value \\
\hline \multirow{4}{*}{ Age (in years) } & $<20$ & $6(6 \%)$ & $8(8 \%)$ & \multirow{4}{*}{0.519} \\
\hline & $21-25$ & $62(62 \%)$ & $52(52 \%)$ & \\
\hline & $26-29$ & $25(25 \%)$ & $33(33 \%)$ & \\
\hline & $\geq 30$ & $7(7 \%)$ & $7(7 \%)$ & \\
\hline \multirow{2}{*}{ Background } & Rural & $65(65 \%)$ & $67(67 \%)$ & \multirow{2}{*}{0.765} \\
\hline & Urban & $35(35 \%)$ & $33(33 \%)$ & \\
\hline \multirow{4}{*}{ Gravida } & G1 & $29(29 \%)$ & $33(33 \%)$ & \multirow{4}{*}{0.804} \\
\hline & G2 & $66(66 \%)$ & $60(60 \%)$ & \\
\hline & G3 & $4(4 \%)$ & $5(5 \%)$ & \\
\hline & G4 & $1(1 \%)$ & $2(2 \%)$ & \\
\hline Gestational age & $\mathrm{MEAN} \pm \mathrm{SD}$ & $37.803 \pm 0.52$ & $37.768 \pm 0.47$ & 0.6005 \\
\hline \multirow{2}{*}{ Previous 1 LSCS } & Yes & $45(45 \%)$ & $52(52 \%)$ & \multirow{2}{*}{0.322} \\
\hline & No & $55(55 \%)$ & $48(48 \%)$ & \\
\hline
\end{tabular}

Table 2: Indication of LSCS.

\begin{tabular}{|lll|}
\hline Indication & $\begin{array}{c}\text { Group A } \\
(\text { study group) }\end{array}$ & $\begin{array}{c}\text { Group B } \\
\text { (control group) }\end{array}$ \\
\hline Breech & $12(12 \%)$ & $10(10 \%)$ \\
\hline Contracted pelvis & $43(43 \%)$ & $42 \%)$ \\
\hline Cephalo-pelvic disproportion & $11(11 \%)$ & $82 \%(17 \%)$ \\
\hline Transverse lie & $11(11 \%)$ & $23(23 \%)$ \\
\hline Previous 1 lscs with associated factors & $23(23 \%)$ & \\
\hline P value $=\mathbf{0 . 6 9 0}$ & & $8 \%)$ \\
\hline
\end{tabular}

Table 3: Primary outcomes.

\begin{tabular}{|llll|}
\hline Parameter & $\begin{array}{l}\text { Group A (study group) } \\
\text { Mean } \pm \text { SD }\end{array}$ & $\begin{array}{l}\text { Group B (control group) } \\
\text { Mean } \pm \text { SD }\end{array}$ & P value \\
\hline Blood loss (in ml) & & & \\
\hline Intraoperative blood loss & $345.98 \pm 79.56$ & $408.6 \pm 63.68$ & $<0.001$ \\
\hline Post-operative blood loss & $114 \pm 19.97$ & $136.38 \pm 24.80$ & $<0.001$ \\
\hline Total blood loss & $459.98 \pm 65.30$ & $554.98 \pm 60.50$ & $<0.001$ \\
\hline Hemoglobin (g/dl) & & & 0.42 \\
\hline Preoperative haemoglobin & $11.14 \pm 0.64$ & $11.21 \pm 0.60$ & 0.038 \\
\hline Post-operative haemoglobin & $10.02 \pm 0.73$ & $9.80 \pm 0.74$ & $<0.001$ \\
\hline Hemoglobin difference & $1.12 \pm 0.36$ & $1.41 \pm 0.39$ & \\
\hline Hematocrit (\%) & & & 0.42 \\
\hline Preoperative haematocrit & $33.43 \pm 1.93$ & $33.64 \pm 1.81$ & 0.038 \\
\hline Post-operative haematocrit & $30.06 \pm 2.20$ & $29.40 \pm 2.23$ & $<0.001$ \\
\hline Haematocrit difference & $3.37 \pm 1.10$ & $4.23 \pm 1.18$ & \\
\hline
\end{tabular}

Table 4: Neonatal outcomes.

\begin{tabular}{|c|c|c|c|c|}
\hline Neonatal outcomes & Variables & Group A (study group) & Group B (study group) & P value* \\
\hline \multirow{3}{*}{$\begin{array}{l}\text { Birth weight } \\
\text { (Kg) }\end{array}$} & $<2.5 \mathrm{Kg}$ & $6(6 \%)$ & $7(7 \%)$ & \multirow{3}{*}{0.939} \\
\hline & $2.5-3 \mathrm{Kg}$ & $62(62 \%)$ & $60(60 \%)$ & \\
\hline & $>3 \mathrm{Kg}$ & $32(32 \%)$ & $33(33 \%)$ & \\
\hline \multirow{2}{*}{$\begin{array}{l}\text { Apgar score } \\
\text { At } 5 \text { min }\end{array}$} & $<7$ & $2(2 \%)$ & $4(4 \%)$ & \multirow{2}{*}{0.342} \\
\hline & $\geq 7$ & $98(98 \%)$ & $96(96 \%)$ & \\
\hline \multirow{2}{*}{ NICU admission } & NO & $95(95 \%)$ & $93(93 \%)$ & \multirow{2}{*}{0.767} \\
\hline & YES & $5(5 \%)$ & $7(7 \%)$ & \\
\hline
\end{tabular}


Regarding indication of caesarean section. In present study we observed that the most common indication of caesarean delivery in study group as well as control group was contracted pelvis (43\% and 42\%) followed by previous 1 caesarean with associated factors $(23 \%$ and $23 \%)$. Other indication were CPD (11\% and 17\%), breech presentation (12 and 10\%) and transverse lie (11\% and 8\%) (Table 2).

In our study the primary outcome was to determine intra operative blood loss and postoperative blood loss (In 1st 24 hours) and to evaluate the difference between preoperative and postoperative hematocrit value and fall in haemoglobin in both groups. In the present study the mean intraoperative blood loss was $345 \pm 79.57 \mathrm{ml}$ which was significantly less compared to control group where it was $408.6 \pm 63.68 \mathrm{ml}(\mathrm{p}<0.001)$ (Figure 1). Mean post-operative blood loss in study group was $114 \pm 19.97 \mathrm{ml}$ which was also significantly less compared to control group where it was $136.38 \pm 24.81 \mathrm{ml}(\mathrm{p}<0.001)$ (Figure 2). The difference in pre and post-operative haemoglobin was lower in study group compared to control group with mean of $1.12 \pm 0.37$ $\mathrm{g} / \mathrm{dl}$ in study group while $1.41 \pm 0.39 \mathrm{~g} / \mathrm{dl}$ in control group $(\mathrm{p}<0.001)$. Similarly, pre and post-operative haematocrit (PCV) difference was significantly lower in study group with a mean of $3.37 \pm 1.10$ in study group versus $4.24 \pm 1.18$ in control group (Table 3 ).

Table 5: Side effects.

\begin{tabular}{|lll|}
\hline Side effects & Study group & Control group \\
\hline No & $81(81 \%)$ & $85(85 \%)$ \\
\hline Pyrexia & $4(4 \%)$ & $2(2 \%)$ \\
\hline Shivering & $7(7 \%)$ & $6(6 \%)$ \\
\hline Diarrhoea & $6(6 \%)$ & $4(4 \%)$ \\
\hline Vomiting & $2(2 \%)$ & $3(3 \%)$ \\
\hline Total & $100(100 \%)$ & $100(100 \%)$ \\
\hline P value $=\mathbf{0 . 8 3 7}$ & & \\
\hline
\end{tabular}

Table 6: Additional uterotonic used.

\begin{tabular}{|lll|}
\hline $\begin{array}{l}\text { Uterotonic } \\
\text { requirement }\end{array}$ & Study group & Control group \\
\hline No & $94(94 \%)$ & $81(81 \%)$ \\
\hline Yes & $6(6 \%)$ & $19(19 \%)$ \\
\hline P value=0.005 & & \\
\hline
\end{tabular}

Most of the newborns had $\mathrm{AS} \geq 7$ at $5 \mathrm{~min}$ in both groups while NICU admissions was noted in 5\% neonate of study group compared to $7 \%$ in control group. Most common indication for NICU admission was respiratory distress.

In this study side effects associated with misoprostol were also noted. In majority, $81 \%$ study group and $85 \%$ control group no side effects were observed. While diarrohea, pyrexia, shivering and vomiting were mild side effects. Most common side effect was Shivering, $7 \%$ in study group and $6 \%$ in control group. The difference was not statistically significant (P-0.837) in both groups.

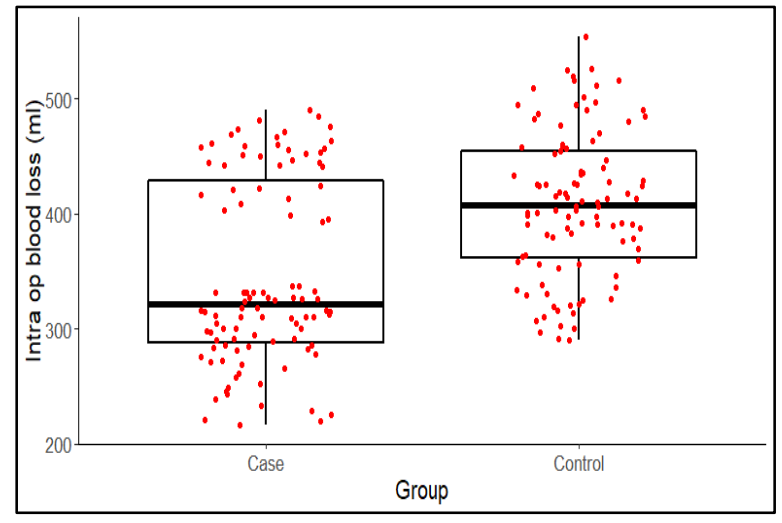

Figure 1: Intraoperative blood loss in case and control group.

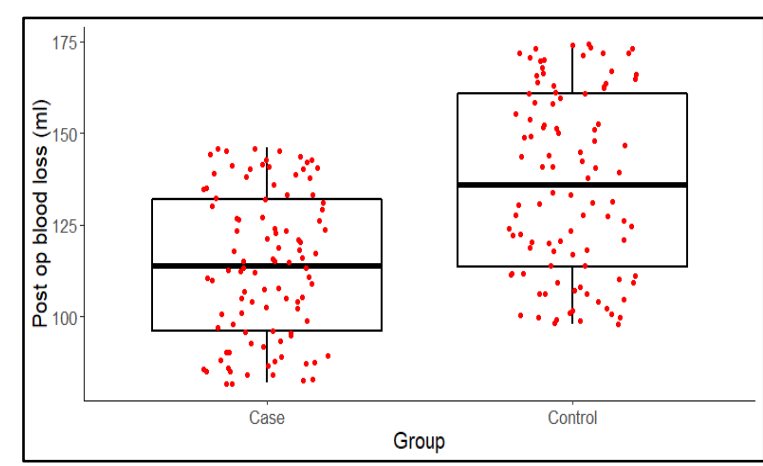

Figure 2: Postoperative blood loss in case and control group.

In present study in majority of subjects no additional uterotonic agent was used. $6 \%$ of subjects in study group and $19 \%$ of subjects in control group needed an additional uterotonic. $\mathrm{P}$ value was 0.005 which was statistically significant. In study group, additional uterotonic used was oxytocin in $5 \%$ of subjects while in $1 \%$ oxytocin + methergin was used. In control group $12 \%$ additional uterotonic used was oxytocin while oxytocin +methergin was used in $5 \%$ and oxytocin +methergin +PGF2 $\alpha$ was used in $2 \%$ subjects of control group (Table 6).

\section{DISCUSSION}

In our study we used $400 \mu \mathrm{g}$ misoprostol via rectal route preoperatively. Routine oxytocin was given to participants in both groups because we were testing the additional value of misoprostol in reducing blood loss rather than directly comparing the two drugs. Pharmacokinetic studies was done by Khan et al found that rectal administration of misoprostol was advantageous because the area under the curve (integral of concentration and time graph) for rectal misoprostol was higher than that for oral misoprostol resulting in a sustained and longer duration of action. ${ }^{10} \mathrm{In}$ present study common side effects of drugs like metallic taste in mouth and nausea, commonly reported problems after sublingual and oral administration were avoided. 
The primary outcome measured in our study were intraoperative blood loss, postoperative blood loss and difference between preoperative and postoperative hemoglobin and hematocrit values.

In our study the mean intraoperative blood loss was lower in study group than control group $345.98 \pm 79.57 \mathrm{ml}(\mathrm{SD})$ $\mathrm{ml}$ versus $408.6 \pm 63.68 \mathrm{ml}(\mathrm{SD})$, respectively $(\mathrm{p}<0.001)$. Similarly in a study done by Kumari et al, the mean intraoperative blood loss was $374 \mathrm{ml} \pm 69$ (SD) in study group (who received pre-operative dose of $200 \mu \mathrm{g}$ of misoprostol tablet per rectally) and in control group (received placebo tablet) it was $401 \mathrm{ml} \pm 79.9$ (SD) difference was statistically significant. ${ }^{11}$ In a prospective study by Kumar, et al with $400 \mu \mathrm{g}$ of sublingual misoprostol, the mean intra-operative blood loss was significantly less in misoprostol group as compared to placebo which is $(595 \pm 108 \mathrm{ml}$ versus $651 \pm 118 \mathrm{ml}$, $\mathrm{p}=0.025) .{ }^{12}$ In a study done by Sitaula $\mathrm{S}$. et al the mean blood loss in study group which received $400 \mu \mathrm{g}$ of misoprostol per rectal preoperatively was $326.7 \pm 106.2 \mathrm{ml}$ whereas group $\mathrm{B}$ which only received oxytocin was $397.7 \pm 110.1 \mathrm{ml}(\mathrm{p}<0.001) .13$ (Table5)

Table 7: Intraoperative Blood loss (in $\mathrm{ml}$ ) comparison between different studies.

\begin{tabular}{|llll|}
\hline Studies & Study group & Control group & $\begin{array}{l}\text { p } \\
\text { values }\end{array}$ \\
\hline $\begin{array}{l}\text { Kumari } \\
\text { et al }\end{array}$ & $374 \pm 69$ & $401 \pm 0.79$ & 0.01 \\
\hline Kumar & $595 \pm 108$ & $651 \pm 118$ & 0.025 \\
\hline $\begin{array}{l}\text { Sitaula } \\
\text { et al }\end{array}$ & $326.9 \pm 116.2$ & $397.7 \pm 110.1$ & $<0.001$ \\
\hline $\begin{array}{l}\text { Present } \\
\text { Study }\end{array}$ & 345.98 & $408.6 \pm 63.67$ & $<0.001$ \\
\hline
\end{tabular}

In the present study the mean postoperative blood loss was significantly less in study group compared to control group $114 \pm 19.97 \mathrm{ml}$ versus $136.38 \pm 24.81 \mathrm{ml}(\mathrm{p}<0.001)$. In a study by Kumari et al the postpartum blood loss was also lower in the study group $131 \pm 31.8 \mathrm{ml}$ than in control group $145 \pm 35.6 \mathrm{ml}$ which is statistically significant. ${ }^{11}$ In Elsedeek et al study with $400 \mu \mathrm{g}$ of preoperatively rectal misoprostol, the mean postpartum blood loss was also lower in study group than in control group $(185 \pm 95 \mathrm{ml}$ versus $324 \pm 167 \mathrm{ml}$; $\mathrm{p}$ value $=0.001) .{ }^{14}$

Table 8: Postoperative blood loss (in $\mathrm{ml}$ ) comparison between different studies.

\begin{tabular}{|llll|}
\hline Studies & $\begin{array}{l}\text { Study } \\
\text { group }\end{array}$ & $\begin{array}{l}\text { Control } \\
\text { group }\end{array}$ & $\begin{array}{l}\text { p } \\
\text { values }\end{array}$ \\
\hline $\begin{array}{l}\text { Kumari } \\
\text { et al }\end{array}$ & $131.8 \pm 31.7$ & $145 \pm 35.6$ & 0.006 \\
\hline Elsedeek & $185 \pm 95$ & $324 \pm 167$ & 0.001 \\
\hline $\begin{array}{l}\text { Present } \\
\text { study }\end{array}$ & $114 \pm 19.973$ & $136.38 \pm 24.80$ & $<0.001$ \\
\hline
\end{tabular}

Our results correlate with these studies revealing significantly less postoperative blood loss in misoprostol group compared to control group $(114 \pm 19.97 \mathrm{ml}$ versus $136.38 \pm 24.81 \mathrm{ml} ; \mathrm{p}<0.001$ ) (Table 6).

In a clinical trial done by Ahmed et al, mean blood loss during and after CS delivery was significantly lower in the pre operatively rectally administered $600 \mu \mathrm{g}$ misoprostol group $620 \pm 291 \mathrm{ml}$ when compared to post-operative rectally administered misoprostol group $898 \pm 321 \mathrm{ml}$ $(\mathrm{p}<0.05) .{ }^{15}$ They also found that postoperative haemoglobin value (after 24 hour) was significantly lower in postoperative rectally administered misoprostol group $(9.8 \pm 1.24 \mathrm{gm} / \mathrm{dl})$ than preoperative misoprostol group $(10.5 \pm 1.31 \mathrm{gm} / \mathrm{dl})$

In our study the difference between preoperative and postoperative haemoglobin value was lower in study group $(1.124 \pm 0.367 \mathrm{gm} / \mathrm{dl})$ than in control group $(1.412 \pm 0.394$ $\mathrm{gm} / \mathrm{dl})$.

In study done by Kumari et al the haemoglobin difference was $1.14 \pm 0.73$ in study group and $1.44 \pm 0.88$ in control group, p value 0.009 which was also statistically significant. ${ }^{11}$ Similar to our study in Sitaula et al, the haemoglobin difference in study group was $1.10 \pm 0.51$ while in control group it was $1.35 \pm 0.49$ with $\mathrm{p}<0.001$ which was significant. ${ }^{13}$

In our study the difference between preoperative and postoperative haematocrit value was also lower in the study group than the control group $(3.372 \pm 1.101$ versus $4.236 \pm 1.184$, $\mathrm{p}$ value, 0.001$)$. our results correlate with Elsedeek et al, who also find that fall in haematocrit level was less in the study group compared control group $(4.62 \pm 2.45$ versus $8.15 \pm 3.84$; $\mathrm{p}$ value $=0.02) .{ }^{14}$ Similarly in a study of Kumari et al the haematocrit difference was significantly lower in the study group than in control group with $\mathrm{p}$ value 0.006 . $^{11}$

\section{CONCLUSION}

The present study was carried out to determine the effect of misoprostol as preoperative medication in reducing blood loss during and after cesarean delivery. In countries where women have severe anaemia during pregnancy because of nutritional and environmental factors, even a reduction of relatively smaller amount of blood loss could be relevant clinically. The proper management of PPH is an essential component of obstetric care and a necessary step to reduce worldwide maternal mortality. In the present study it was concluded that preoperative $400 \mu \mathrm{g}$ rectal misoprostol is effective in reducing intraoperative and postoperative blood loss, thus preventing postpartum hemorrhage and reducing incidence of overall maternal morbidity and mortality. Further it is easily available, cheaper, stable at room temperature and with ease of administration seems to be a better option in low resource settings. 
Funding: No funding sources

Conflict of interest: None declared

Ethical approval: The study was approved by the Institutional Ethics Committee

\section{REFERENCES}

1. WHO maternal mortality Fact sheet Updated November 2016. https://www.who.int/newsroom/fact-sheets/detail/maternal-mortality. Last accessed on 14 October, 2019.

2. Postpartum hemorrhage - World Health Organization. https://www.who.int/medicines/areas/priority_medici nes/Ch6_16PPH.pdf. Last accessed on 14 October, 2019.

3. Theresa A. Lawrie, Ewelina Rogozińska, Pauline Sobiesuo, Joshua P. Vogel, Laura Ternent, Olufemi T. Oladapo A systematic review of the costeffectiveness of uterotonic agents for the prevention of postpartum hemorrhage Int J Gynecol Obstet. 2019

4. Bajwa SK, Bajwa SJS, Kaur H, Goraya SPS, Singh A et al. Management of third stage of labor with misoprostol: A comparison of three routes of administration Perspect Clin Res. 2012;3(3):102-8.

5. Gallos ID, Williams HM, Price MJ, Merriel A, Gee $\mathrm{H}$, Lissauer D et al. Uterotonic agents for preventing postpartum haemorrhage: a network meta-analysis. Cochrane Database Syst Rev. 2018;4:CD011689.

6. Udayan MA, Hareshbhai PP. A Study on efficacy and safety of the drug misoprostol $600 \mathrm{mcg}$ for prevention of postpartum hemorrhage by different routes of administration in routine management of 3 stage of labor; a randomized placebo controlled double blind study. I.M.A.G.S.B. NEWS BULLETIN / AUGUST - 2014;9(8). imagsb.com/uploads/bulletin/August2014.pdf. Accessed on 14 October, 2019

7. Goldberg AB, Greenberg MB, Darney PD. Misoprostol and Pregnancy January 4, 2001 N Engl J Med. 2001;344:38-47.

8. Tang O, Gemzell-Danielsson K, H PC. Misoprostol: Pharmokinetic profiles, effects on the uterus and side- effects International Journal of Gynecology and Obstetrics. 2007;99:S160-S167.

9. Mirteimouri, Tara M, Teimouri F, Sakhavar B, Vaezi N, Afsaneh. Efficacy of Rectal Misoprostol for Prevention of Postpartum Hemorrhage. Iranian journal of pharmaceutical research: IJPR. 2019;12;469-74.

10. Rehan K, El-Refaey, Hazem. Pharmacokinetics and Adverse-Effect Profile of Rectally Administered Misoprostol in the Third Stage of Labor. Obstetrics and gynecology. 2003;101:968-74.

11. Kumari A, Swathi E, Saranu S. Impact of preoperative $200 \mu \mathrm{g}(\mathrm{P} / \mathrm{R})$ per rectal misoprostol on blood loss during and after Cesarean delivery. IAIM. 2016;3(6):49-58.

12. Sood, A.K., Singh, S. Sublingual Misoprostol to Reduce Blood Loss at Cesarean Delivery. J Obstet Gynecol India. 2012;62:162-167.

13. Sarita S, Uprety DK Achala T, Tarun P. Impact of Preoperative Rectal Misoprostol on Blood Loss during and after Elective Cesarean Delivery: A Randomized Controlled Trial. Nepal Journal of Obstetrics and Gynaecology. 2017;11:37.

14. Mervat SEA. Elsedeek. Impact of preoperative rectal misoprostol on blood loss during and after elective cesarean delivery. International Journal of Gynecology \& Obstetrics. 2012;118(2):14-9152.

15. Ellah A, Tamam A, Khodry A, Mostafa. Is the Time of administration of misoprostol of value? The uterotonic effect of misoprostol given pre- and postoperative after elective cesarean section. Middle East Fertility Society J. 2013;19:10.

Cite this article as: Karya U, Maheshwari S, Rani A. Uterotonic effect of rectal misoprostol as preoperative medication for assessment of intraoperative and postoperative blood loss in cesarean delivery. Int J Reprod Contracept Obstet Gynecol 2021;10:1415-20. 